\title{
"Se aqui é o inferno, eu sou a principal demônia!": Etnografando agências juvenis LGBT em contextos escolares de Fortaleza (CE)
}

\author{
JOSÉ RICARDO MARQUES BRAGA
}

UNIVERSIDADE FEDERAL DO RIO GRANDE DO NORTE (UFRN), NATAL/RN, BRASIL HTTPS://ORCID.ORG/OOOO-0003-I304-5243

\section{Introdução}

A reflexão que se materializa nas próximas páginas é fruto de trabalho de campo realizado em três escolas públicas da cidade de Fortaleza (CE), localizadas na região oeste, área considerada periférica, apresentando, de maneira geral, características socioeconômicas similares. Todas as escolas investigadas estão situadas em zonas consideradas estigmatizadas pelos altos índices de violência urbana e baixo Índice de Desenvolvimento Humano (IDH) ${ }^{1}$. Os estudantes são considerados pelos agentes escolares "filhos de pobres", de "famílias desestruturadas" e "filhos dos becos". Eu fui interpelado diversas vezes, tanto por amigos como pelas próprias pessoas que trabalhavam nessas instituições, sobre se não teria "medo" de fazer pesquisa ali naquela região.

O trabalho de campo integra uma etnografia que orbita em torno da compreensão das experiências de jovens estudantes que compartilham - assumidamente - sexualidades tidas por periféricas e/ou identidades de gênero fora das performances hegemônicas, que rompem com a ideologia da complementaridade dos sexos, tão naturalizada pelas instituições escolares (Bento, 2011). A intenção do artigo é explorar a miscelânea de experiências de estudantes $\mathrm{LGBT}^{2}$ que tomam lugar no seio das

1 O IDH é mensurado a partir de três variáveis: educação, renda e saúde.

2 Uso este acrônimo, apesar da divergência de apresentação, fomentada pelos movimentos sociais, entre outros, por ser essa a definição defendida e aprovada na I Conferência Nacional de Lésbicas, Gays, Bissexuais e Travestis, em Brasília, no ano de 2008. As conferências posteriores (2011 e 2016) mantiveram essa sigla. 
instituições de ensino investigadas, compreendendo a relação que estabelecem com o universo educacional e analisando como tais jovens, considerando sua sexualidade, experimentam o tempo da escola. Os resultados sinalizam uma forte heterogeneidade das relações travadas nesse espaço por parte dos estudantes LGBT, pois, apesar de a escola ser tida como instituição que visa a subordinar as sexualidades e identidades não hegemônicas, essas juventudes encontram múltiplos meios para permanecer nesse universo e tentar uma transformação das regras que operam nesse local.

Partindo do princípio de que a "pedagogia da sexualidade" (Louro, 2000) implantada nas escolas marginaliza e violenta identidades em dissonância das normas dominantes, produzindo seres considerados abjetos que vão sendo gradualmente expulsos de tais espaços (Bento, 2011; Costa Novo, 2015; Oliveira, 2017), interessa observar os meandros dos cotidianos educacionais para perceber como se constroem as relações desses jovens com os ambientes de ensino e os atores sociais que os compõem, como gestores, professores, funcionários e toda a comunidade escolar. Pretendo mostrar que, mesmo não negando as mais diversas formas de violência, negação e invisibilidade aos quais estão sujeitos, esses jovens produzem estratégias de sobrevivência, construindo linhas de fuga que permitem, em alguns casos, a ressignificação da escola e uma apropriação possível da instituição por esses estudantes.

Além de jovens gays, lésbicas e bissexuais - estes últimos silenciados nas abordagens socioantropológicas sobre sexualidades, como sugerem Simões e Carrara (2014) - o quadro etnográfico que compõe a pesquisa conta também com uma estudante que se declara como travesti e/ou "bicha afeminada" (tal classificação se mostra fluida, sendo acionada de distintas maneiras em situações diferentes). Por isso essa aluna entende viver uma situação ainda mais delicada que os demais, uma vez que "mesmo entre os gays, é notório que a violência mais cruenta é cometida contra aqueles que performatizam uma estilística corporal mais próxima do feminino” (Bento, 2014:1).

Andrade (2012) afirma que as travestis na escola são vistas como "poluidoras" do ambiente, precisando, a todo custo, ser corrigidas, para não influenciarem os meninos. A autora, embora considere um cenário menos tenebroso que anos atrás, entende que a instituição escolar é falha no tratamento da diversidade, tolerando, na melhor das hipóteses, a presença das travestis, mas as expulsando simbolicamente desse espaço, numa espécie de "evasão involuntária".

Aqueles que não inscrevem em seus corpos os sinais da masculinidade/feminilidade impostos e que, portanto, não exibem uma concordância entre gênero, sexualidade e corpo (Bento, 2006), estão sujeitos a um percurso escolar marcado pela violência, seja física ou moral. Não quero aqui afirmar com isso que todas as experiências de corpos LGBT nos espaços educacionais devam ser tomados pelo prisma da violência, da negação e do sofrimento, pois entendo que a escola é plural e não monolítica, assim, diversas são as experiências que podem ser vividas por esses estudantes. Apenas sinalizo que as formas de experimentar a escola são condicionadas por diversos marcadores, incluindo o gênero e a sexualidade, fazendo com que aqueles fora da norma tenham um percurso mais dificultado.

Dessa forma, afrontar as formas idealizadas do gênero e/ou da sexualidade impõe aos sujeitos itinerários de exclusão implícita - através do silenciamento e invisibilização - ou explícita, por meio de tratamento discriminatório, que se materializa em piadas, insultos e ritos de suplício na convivência educativa. São os percursos construídos entre os muros escolares por esses jovens estudantes - que, 
longe de se constituírem numa uniformidade, são multidimensionais, plurais e complexos - a preocupação central da reflexão aqui proposta.

A discussão empreendida mostra-se de fundamental importância nos tempos em que vivemos, nos quais há uma série de contendas políticas sobre as questões de gênero e sexualidade nas escolas, notadamente com o advento daquilo que os conservadores denominam de "ideologia de gênero". Para esses setores, conforme Junqueira (2018), o campo de estudos de gênero, que se consagrou desde os anos 1980, constitui-se em um ataque à família (na verdade, a um padrão familiar), por propor a desconstrução de princípios biológicos e teológicos que eram naturalizados até então. Assim, o sintagma "ideologia de gênero" é, na verdade, uma disputa narrativa que deseja manter a escola e seus agentes como reprodutores das normas hegemônicas, na tentativa de calar os setores progressistas e barrar as relativas conquistas dos direitos adquiridos por mulheres e LGBTs, por exemplo. Configura-se, portanto, como mais um entrave construído para dificultar o avanço dos corpos e das subjetividades tidos por desviados na escola - e no mundo.

\section{Escola, a construção do discurso sobre a sexualidade e a produção de corpos e subjetividades}

Foucault (1988), em contraposição ao que denomina de "hipótese repressiva" - ideia que afirma a interdição, censura e negação do sexo no século XIX - entende que a história do sexo não se reduz à repressão, engendrando, assim, instâncias de produção discursiva. $\mathrm{O}$ sexo, desde então, foi sendo colocado num mecanismo de crescente incitação discursiva: “' [...] constituiu-se uma aparelhagem para produzir discursos sobre o sexo, cada vez mais discursos, suscetíveis de funcionar e de serem efeitos de sua própria economia" (Foucault, 1988:26).

Segundo esse autor, as instituições escolares foram largamente utilizadas na inserção do sexo num sistema de utilidade. Esses estabelecimentos, já a partir do século XVIII, produzem e transmitem às crianças um conteúdo limitado e canônico ou, nas palavras de Foucault, uma verdadeira "ortopedia discursiva", regulando-a pela produção de tratados e não pela sua proibição, instalando uma polícia do sexo e exigindo procedimentos de gestão, que tenderiam a fabricar corpos e subjetividades "saudáveis".

Em consonância com Foucault (1988), penso a escola como locus de governamentalidade do Estado moderno, com vistas à produção de corpos e subjetividades. É nesse espaço que se produz - ou se tenta produzir - a cisgeneridade e a heterossexualidade desejáveis, ensinando em tudo, nos detalhes mais triviais do cotidiano, o modelo dominante, bem como introjetar nos jovens estudantes os padrões de feminilidade e masculinidade hegemônicos, como pude observar diversas vezes em campo, apontando e reiterando o "jeito certo" de ser homem e mulher.

Em uma dessas incursões, numa escola a que tive acesso por conhecer um dos professores, que facilitou minha inserção, observei - por não poucas ocasiões - como a instituição e seus agentes funcionam como canais pelos quais o poder atinge as mais individuais das condutas, penetrando nos corpos juvenis de forma quase imperceptível. Eu acabara de chegar à escola e estava soando a música que toca às sete horas da manhã, sinalizando o início das aulas. Nesse momento, os alunos se dirigiam para 
suas salas, alguns conversando nos corredores, outros arrumando seus cabelos e maquiagens com um pequeno espelho, enquanto alguns ainda estavam sentados nos bancos do pátio. Ao passar por perto destes últimos, cumprimentando-os, vejo um professor se dirigir a um dos garotos sentados, exortando-o a sentar-se "direito, como homem", ao mesmo tempo em que com suas mãos descruzava as pernas do jovem, encaminhando-o para sua sala.

Antes de prosseguir, gostaria de fazer mais um relato significativo da produção do gênero e da sexualidade pela escola, enquanto aliada da família num "projeto normalizador" do menino e da menina, como sugere Seffner (2011). Numa das idas a campo, estava de olho no diálogo travado entre um funcionário da secretaria e uma mãe que indagava sua "estranheza" em ver algumas meninas praticando "queda de braço", sugerindo que seria "coisa de homem" ${ }^{3}$. Logo em seguida, argumentando que aquela era uma "prática perigosa”, o funcionário logo interrompe a diversão das meninas.

Cenas dessa natureza se repetiram ao longo do período de campo e muitas outras, não observadas, mas narradas - por vezes com tom de sofrimento, outras de deboche - pelos estudantes chegaram a meu conhecimento. Em outra escola, conheci uma jovem lésbica, cursando o último ano do Ensino Médio, que afirmou que desde os quinze anos de idade tinha optado por usar o cabelo curto - "igual de homem", conforme suas próprias palavras - e isso lhe conferiu graves constrangimentos durante as aulas.

Em um destes, a garota me conta, por exemplo, que era constantemente indagada pelos professores e demais funcionários sobre a opção de corte de cabelo que fizera. Certa vez, durante a aula, em um tom que oscilava entre zombaria e desrespeito, um docente confundiu-a com um rapaz, chamando-a por nome masculino, o que foi suficiente para todos os colegas rirem da garota que, sem reação, calou-se e "deixou por isso mesmo", de acordo com seu relato.

Outra forma da regulação - e produção específica - da sexualidade por meio da ação discursiva aparece na conversa com Leonardo ${ }^{4}$, jovem de 17 anos que cursava o último ano do Ensino Médio. O rapaz, assumidamente gay, afirma que uma professora de Biologia, certa vez, ao falar sobre reprodução, utilizou uma retórica eminentemente religiosa para se referir à existência de homens e mulheres conforme a "vontade divina". Assim, para a docente, aqueles que trazem um pênis como genitália são homens e devem, portanto, de forma natural, se sentirem atraídos afetivo-sexualmente por mulheres, que, por sua vez, são aquelas que portam uma vagina desde o nascimento e, consequentemente, sentem-se atraídas por homens.

Segundo Leonardo, para a tal educadora, não haveria outra possibilidade de existir no mundo fora desses padrões instituídos e aqueles que tentam desviar-se dessa norma estariam destinados a ficar fora do "Reino de Deus", discurso que certamente reverbera na conduta e subjetividades dos jovens, uma vez que escutam esse posicionamento de uma professora, a qual teria, em tese, autoridade para discutir o assunto. Assim, observamos como a escola impõe uma verdadeira "ortopedia discursiva” do sexo (Foucault, 1988), isto é, estabelece e fixa um "certo discurso razoável, limitado, canônico e verdadeiro sobre o sexo" (ibid.:31), que impacta os sujeitos que partilham desse espaço.

3 Atividade esportiva/recreativa em que dois contendores, com um dos cotovelos apoiados sobre superfície horizontal, enlaçam as mãos ou os punhos e, cada um, aplicando força muscular, tenta fazer o adversário derrubar o braço.

4 Os nomes aqui utilizados são fictícios. 
Por conseguinte, o trabalho de campo e as conversas com os jovens, professores e gestores me mostraram aquilo que denominei inicialmente como "aparente paradoxo". Se, por um lado, é formalmente assumido que a instituição escolar é um "lugar neutro" em relação à sexualidade, que não fala ou incita questões relacionadas ao tema e, sobretudo, que não há nenhum tipo de discriminação e preconceito em relação àqueles que não seguem a norma heterossexual - discurso sustentado, sobretudo, pelos membros dos núcleos gestores das escolas -, o campo e as vivências decorrentes deste apontavam o tempo inteiro para a instituição como locus do regulamento e da produção de uma dada sexualidade - inclusive, infligindo sobre os corpos desviados uma punição, ora mais velada, ora mais explícita 5 .

Contudo, desejo afirmar que essa não é uma contradição em si. Advogo que o discurso de respeito à diversidade e a neutralidade com que os agentes escolares afirmam tratar todos é a própria condição para as violências engendradas contra os corpos LGBT na escola - sem ele, não seria possível mascarar a diferença e usá-la para criar as desigualdades existentes nesses espaços. É pela e com a suposta igualdade que se fabrica a desigualdade.

Dessa forma, se os relatos verbais das autoridades escolares apontavam para uma ausência de diferenciação entre os jovens, de acordo com sua sexualidade e/ou identidade de gênero, não era isso que encontrava nas minhas observações, tampouco era a forma com que os próprios estudantes viam esses espaços. O que observava era o uso das mais corriqueiras práticas para modelar aqueles estudantes que desviavam dos padrões hegemônicos da cisgeneridade e da heterossexualidade. E isso era percebido e trazido à baila pelos próprios jovens.

Os relatos dão conta de uma perceptível diferença, por exemplo, de como se sentem antes e depois do "assumir-se" fora da norma e, quando isso acontece, percebe-se uma tentativa de trazê-los de volta para o espectro da "normalidade". Em consonância com Foucault (1988:27), "olhando para os regulamentos de disciplina e toda a organização interior lá se trata continuamente de sexo". Trata-se de uma produção contínua de uma sexualidade e/ou gênero em conformidade com as convenções culturais da sociedade moderno-ocidental.

A construção e a classificação do sexo são realizadas continuamente, da entrada à saída, no intervalo e no horário de aulas e até mesmo nos atos e nas formas de comunicação mais triviais. Nesse sentido, é significativo o fato de, certa vez, na secretaria de uma das escolas, ter escutado de uma funcionária que não poderia fornecer para um aluno folhas de papel de cor rosa - solicitadas pela professora de Artes -, pois isso "induziria" o jovem a desviar-se do caminho da heterossexualidade, o que, para esta mesma funcionária, já estava ocorrendo, porque o rapaz utilizava brincos nas orelhas.

Também nessa escola, pude presenciar outro momento emblemático e revelador. Durante o intervalo, alguns alunos e alunas praticavam esportes nas duas quadras disponíveis e em outros pequenos espaços improvisados. As bolas ficam guardadas na direção, que as distribui quando solicitadas pelos estudantes. Entretanto, às meninas não são disponibilizadas as bolas de futebol, apenas as de vôlei ou de handebol, estas interditadas para os garotos, numa clara demonstração de generificação das ativi-

5 Entendo que o discurso progressista sobre a paridade de tratamento dos sujeitos escolares está imerso no contexto de proliferação de um debate sobre democracia, gênero e sexualidade, que emerge, sobremaneira, a partir de 1995, com a IV Conferência Mundial sobre a Mulher, na China, onde se projeta uma agenda política de luta pela igualdade de gênero, confrontando os interesses de setores conservadores (Miskolci e Campana, 2017). 
dades que têm lugar nessas instituições. Na prática, algumas meninas - poucas - jogam futebol com os meninos e os meninos jogam vôlei e/ou handebol com as meninas, mas a ordem é só distribuir as bolas de acordo com o sexo daquele ou daquela que irá buscar na direção, colaborando para pensarmos quanto o espaço social escolar, as práticas e dinâmicas engendradas nele são generificadas. Podemos observar, dessa forma, em consonância com Vianna e Lowenkron (2017), que os processos de Estado, operados através de seus agentes de autoridade - funcionários das escolas - articulam relações e violências de gênero.

O universo educacional, assim, constitui-se como "panóptico dos gêneros" (Bento, 2006), construindo corpos e subjetividades pautados em ajustamentos contínuos e afirmações, fazendo com que crianças e jovens interiorizem os enunciados performativos e uma estilística que os deveria levar a uma cisgeneridade e heterossexualidade, que nada têm de natural, segundo Bento (2006) e Louro (2000, 2014).

De acordo com Bento (2006:88), "a heterossexualidade não surge espontaneamente em cada corpo recém-nascido, inscreve-se reiteradamente por meio de operações constantes de repetição e de recitação dos códigos socialmente investidos como naturais", processo no qual a escola demonstra importância salutar, em momentos como os mencionados, oriundos da pesquisa de campo. Rich (2010), ao analisar o que denomina de "heterossexualidade compulsória", também compreende que o desejo nesses moldes, longe de ser natural, é criado pela ordem social na qual estamos inseridos, sendo reproduzido como imanente a todos os sujeitos, o que acaba por gerar naqueles que não o possuem um sentimento de desajuste.

As crianças e jovens "desajeitados", aqueles em não conformidade com aquilo que Rubin (1986) chama de "sistema sexo-gênero" - suposta equivalência natural entre sexo e gênero - sofrem os terríveis efeitos das mais diversas violências no espaço escolar. $\mathrm{O}$ tratamento discriminatório, seja dos próprios colegas ou professores, é elemento basilar nos discursos desses estudantes. Não era incomum, durante o trabalho de campo nas escolas, a passar nos corredores, que ouvisse palavras como "viado" e "mulherzinha" dirigidas àqueles meninos que não performavam uma masculinidade esperada ou "sapatão" e "macho-fêmea" para aquelas meninas que fugiam dos padrões de feminilidade instituídos. O próprio pesquisador, que durante esse período compunha o cenário escolar, não escapava de ser alvo do mesmo escárnio, o qual atinge também professores que não sustentam uma estilística esperada.

Devo salientar que, quanto mais esses jovens borram as fronteiras do gênero, mais se exerce sobre eles uma pedagogia da desmoralização, acentuando-se situações degradantes, através de insinuações, piadas, apelidos e, algumas vezes, agressões físicas. Pesquisa realizada pelo Instituto de Estudos e Pesquisas Educacionais (INEP) corrobora as dificuldades enfrentadas pelos discentes LGBT, ao apontar que $87 \%$ daqueles que integram a comunidade escolar no país possuem preconceito relacionado à orientação sexual (Brasil, 2009). Segundo Oliveira (2017), os espaços escolares estão, a todo momento, reafirmando a superioridade cisgênero e heterossexual, lançando para as margens aqueles desviantes das normas hegemônicas, impondo obstáculos quase intransponíveis a estes, enquanto os normatizados desfrutam dos privilégios que o modelo dominante lhes traz. 
Inspirada em Foucault, Louro (2000) coloca que a formação do alunado, nos seus mais diversos aspectos - currículo, normas, linguagens, materiais didáticos e processos avaliativos - informam que tipo de corpo e sexualidade pretende se construir nos espaços de ensino, portanto. Assim, como demonstramos, através de múltiplos e discretos mecanismos - ora mais velados, ora mais explícitos - a escola produz, distingue e classifica corpos e mentes. As formas idealizadas dos gêneros - aprendidas nela e em outras instituições - produzem efeitos na vida de crianças e jovens, pois constroem exclusões, bem como a ausência de legitimidade de maneiras outras de viver e estar no mundo.

Nesse sentido, tenta-se aprisionar o corpo por interdições e obrigações, com vistas a performar uma masculinidade/feminilidade aprendida desde a mais tenra infância e exigida nos mais diversos espaços experimentados. $\mathrm{E}$ as crianças e jovens estudantes que estão fora desses padrões? Como vivem e experimentam o espaço escolar fora das idealizações do gênero? Como seus corpos se expressam em dissonância de uma performatividade esperada? Como lidam com um corpo que "denuncia" reiteradamente sua homossexualidade e/ou ausência de masculinidade?

\section{Meninos afeminados, (a ausência da) produção da masculinidade e experiências de uma travesti na escola}

Guilherme é um jovem de 16 anos, estudante de uma das escolas investigadas. Conheci o garoto durante um ensaio de um espetáculo de que ele participava, junto com cerca de cinco meninas. Guilherme ensaiava no pátio da escola uma peça teatral para avaliação de uma disciplina e, no momento em que o vi, estava dançando uma música conhecida entre os grupos LGBT dos anos 1990/2000. Chamou minha atenção pelo talento com que encenava a coreografia e decidi me aproximar assim que possível. No dia seguinte pude conversar com o estudante no intervalo, inicialmente sobre a música que o vi dançando no dia anterior. Dessa forma, Guilherme falou de seu gosto pela dança e demonstrou ser um exímio conhecedor de músicas de estilo pop, revelando também possuir um grupo de dança no seu bairro e sempre se envolver com tais atividades na escola. Contudo, nem sempre havia sido dessa forma.

A dança sempre foi seu encanto, conforme relata. Mas as dificuldades, inicialmente, se mostraram enormes, por inúmeros motivos. Na escola, por exemplo, tinha vergonha de assumir que apreciava dançar, já que esta é uma prática socialmente considerada feminina e por saber, assim, que seus amigos zombariam ao saber do seu gosto. Como as atividades escolares são atravessadas pelo gênero, reproduzindo o mundo social que toma o corpo como "realidade sexuada" e signatário de uma "divisão sexualizante" (Bourdieu, 2002), cabia ao garoto se interessar pelo futebol que, naquele contexto, ocupa o lugar de prototípica instituição masculina, tal qual o boxe na realidade do gueto estudada por Wacquant (2000).

Guilherme chegou a relatar que o gosto por atividades artísticas vinha desde cedo, mas a família - assim como a escola - o impeliu a adentrar num universo tido como masculino. A própria mãe, ao ver certa vez o filho dançando e "rebolando como uma menina", conforme Guilherme afirma, deu uma surra no garoto, com cerca de dez anos de idade na época, buscando corrigir a postura indesejada. Episódio similar relatado pelo jovem foi outra surra que sua mãe lhe deu, ao lhe surpreender brincando 
com as bonecas de sua irmã, quando tinha aproximadamente cinco anos, mostrando que a violência ainda se apresenta como solução para possível "correção" da criança quando esta deseja usar brinquedos - ou roupas, por exemplo - que não se adequam ao seu gênero (Bento, 2014). Ainda hoje, o jovem afirma ter uma relação fundamentada no conflito com a mãe que, sempre que pode, xinga-o e o bate.

A figura materna para Guilherme é compreendida pelo viés do medo e do rancor, o que nos faz repensar, com Badinter (2011), a concepção naturalizada e romantizada da mãe nas sociedades ocidentais modernas, em que esta seria símbolo do cuidado e do afeto. A família, representada sobretudo pela mãe, delineia-se como estrutura de poder que buscava, sempre que possível, moldar o jovem dentro de parâmetros estabelecidos da masculinidade, pois um filho gay - principalmente com comportamentos tidos como femininos - era o medo nesse espaço, de onde chegou a partir uma tentativa de expulsá-lo de casa quando surgiram rumores de que mantinha relações sexuais com um dos vizinhos. Hoje, Guilherme afirma que não tem uma família que o apoie e o ame, mas que apenas o cobra e o agride, o que aponta para o fato de a homossexualidade equivaler, muitas vezes, à exclusão do modelo familiar (Grossi, 2003).

Na escola, também desde cedo, Guilherme aprendeu que não poderia adotar determinadas condutas, mas deveria aprender um repertório estilístico que era tradicionalmente masculino. Afirma que sempre se sentiu deslocado entre os meninos, por não compartilhar de um habitus similar, e isto lhe causou uma série de momentos de sofrimento. Xingamentos como "viadinho", "bichinha”, "mulherzinha" fazem parte de suas memórias escolares desde os primeiros anos, o que o fez, durante certo tempo, tentar modificar a si mesmo e a seus gestos corporais, pois, como coloca Connell (1995), masculinidades são corporificadas.

Dessa maneira, as masculinidades são vivenciadas e performadas "em parte, como [...] posturas, habilidades físicas, formas de nos movimentar" (Connell, 1995:189). Cansado de sempre ser alvo de deboche ao passar nos corredores da escola, Guilherme relata que chegou ao ponto de pagar a alguns meninos da rua onde morava para lhe "ensinarem a andar como homem" e a jogar futebol, empreendimentos sem êxito, conforme o jovem. Observa-se, assim, como a tentativa de adequação à norma é um tempo de sofrimento, marcado por dificuldades e crises pessoais. Dessa forma, a virilidade, "construída diante de outros homens, para outros homens e contra a feminilidade" (Bourdieu, 2002:67), é imposta a todos os meninos desde muito cedo, segregando aqueles que não se enquadrarem nestes moldes daqueles que se adaptaram a eles. Os homens, assim, precisam ininterruptamente reafirmar sua força, honra, virilidade e capacidade, reproduzindo esquemas mentais constituídos historicamente.

Isso faz com que, conforme Bourdieu (2002), sejam também vítimas da "dominação masculina”, ideia que rendeu a esse autor fortes críticas feministas, ao entender não unicamente como dominação aquela de um sexo sobre outro, já que tanto homens como mulheres aparecem inseridos na mesma ordem simbólica ${ }^{6}$. Dessa forma, os próprios homens têm seus percursos marcados pela tensão de sustentar o padrão de masculinidade exigido pela ordem social. Connell (1995) também acredita que os

6 Machado (2014), por exemplo, critica Bourdieu ao afirmar que, embora compartilhem os mesmos códigos culturais, homens e mulheres percebem tal dominação de maneiras distintas, uma vez que suas posições relacionais na ordem social diferem. 
homens pagam o preço da manutenção de uma ordem de gênero não igualitária, que atinge mulheres, mas também homens com performance "afeminada".

Para Berenice Bento (2014), ao refletir sobre o transfeminicídio no Brasil - país que mais mata travestis e transexuais no mundo - a desvalorização do feminino é potencializada quando sua estilística é encarnada por corpos que nasceram com pênis. No imaginário social, há o entendimento cartesiano de que os cromossomos e hormônios, naturalmente, irão fabricar comportamentos e performances de acordo com cada sexo. Dos homens, portanto, espera-se determinada atuação social em consonância com o pregado pela consciência coletiva e que, assim, aja enquanto "homem, macho e viril", expulsando de suas expressões toda e qualquer marca do feminino.

Com o decorrer do tempo, Guilherme deixou de buscar modificar a si próprio e a "não ligar para o que os outros dizem", como me informou. Na atualidade, disse comportar-se como queria: dançando em casa - não sem represálias - e na escola; utilizando, vez por outra, uma leve maquiagem (o que lhe rendia puxões de orelha repetidamente); mostrando orgulhoso um caderno de cor predominantemente rosa, o que sempre quis, mas com cujos custos - simbólicos - de portar tal objeto só há pouco tempo tinha se disposto a arcar. Nos primeiros dias em que resolveu afirmar na escola o comportamento desejado e não o que lhe era imposto, Guilherme ainda passou por muitos momentos de sofrimento e humilhação entre os colegas, que lhe proferiam vários insultos. Porém, segundo o estudante, "o pessoal se acostumou e hoje é menos essas coisas".

Segundo Eribon (2008), a eficácia das injúrias dirigidas aos gays está no seu poder de sujeição. Através da linguagem, os indivíduos adentram numa relação hierárquica que atribui ao sujeitado aquele que recebe o insulto - um lugar subalterno. A partir do momento em que Guilherme, ao receber xingamentos e insultos por sua homossexualidade, não se sujeita ao lugar desvalorizado que querem lhe atribuir ao lhe chamar de "viadinho", a tentativa de ofensa não se efetua e o jovem consegue sustentar sua existência, mesmo em um meio pouco afeito a recebê-lo.

O itinerário de Guilherme aponta para uma relação atual menos conflituosa com a escola, principalmente com os colegas. É a possibilidade, nos seus termos, do encontro com as "bichas" amigas, uma fonte de diversão e também de "fechação". Neste último caso, quando de algum problema por conta da sua forma afeminada de se comportar, as amigas "entram em ação", pois são "todas por todas". Acrescentou que uma coisa boa da escola é poder adotar esse comportamento mais afeminado, interditado para alguns sujeitos fora dos muros escolares. Todavia, conta que algumas mais "quietinhas" preferem não entrar em contendas na escola e "deixam para serem bichas só lá fora”. Dessa maneira, aponta como "ser bicha" na escola, de qualquer modo, se caracteriza como problema e é algo malvisto, pois essas mais "quietinhas", que se enquadram numa postura mais masculina, construiriam melhores relações naquele espaço. São, assim, estratégias diferentes na apropriação do cotidiano educacional.

Os meninos que não se adequam aos padrões estabelecidos da masculinidade, logo, experimentam a escola como lugar de horror - embora, como vimos no caso de Guilherme, possa haver resistência diante dos atos de inferiorização. As piadas, os insultos e as agressões físicas fazem parte do cotidiano daqueles que se desvirtuam do paradigma convencional: o homem como ser viril, forte, inserido no mundo público e distante da dimensão afetiva. 
Ao defender uma recomposição dos elementos de gênero, Connell (1995) busca uma nova política que liberte os homens - e também as mulheres - do pensamento dominante estruturado historicamente, que estabelece uma rígida distinção entre os sexos. Com efeito, defende que é necessário "tornar toda a gama do simbolismo e da prática do gênero disponível para todas as pessoas [...] e encorajar garotos e garotas a expandirem suas opções de ação e se movimentar nas diferentes posições de gênero" (Connell, 1995:200). Dessa forma, uma efetiva política do gênero, tal qual defendida pelo autor, faria com que esses garotos não adotantes de uma masculinidade esperada produzissem novos estilos de pensamento e comportamento, que oferecessem experiências plurais e, desse modo, também respeitadas e valorizadas.

Outra história marcada por rupturas e sofrimentos é a de Rebeca, jovem de 18 anos, aluna do primeiro ano do Ensino Médio de uma das escolas investigadas, que se identifica como travesti. Conheci Rebeca também nos corredores, no horário de intervalo. Sempre simpática, dispôs-se a dialogar comigo durante alguns dias, quando possível. Em certas ocasiões, durante o intervalo, explicava-me que não poderia conversar, pois iria jogar vôlei com amigas na quadra da escola. Afirmou que desejava "explorar" tudo que a instituição escolar tinha para oferecer: as amizades, os jogos, as paqueras, os aprendizados, dentre outros, já que nem sempre foi assim e um dia foi levada a abandonar a sala de aula. No seu discurso, era forte o tom acusatório usado para definir a escola, pois essa instituição havia lhe "roubado" momentos e vivências importantes.

A existência de Rebeca no universo educacional é um daqueles casos que chacoalham a coerência compulsória construída no pensamento ocidental, que atribui suposta congruência entre macho/ pênis/homem/masculino e fêmea/vagina/mulher/feminino. Rebeca construía performativamente sua identidade de gênero, repetindo atos, gestos e signos que, na inscrição cultural nossa, estão no campo do feminino. Seus cabelos longos, rosto sempre maquiado, suas roupas justas e curtas configuravam atos intencionais que produziam significados, como pontua Butler (2003).

Recordando de suas primeiras memórias escolares, Rebeca relatou momentos em que era agredida - física e verbalmente - e, naquele período, sequer conseguia elaborar uma razão para aquilo que acontecia. Com o passar dos anos, percebeu que o fato de ser uma criança com uma existência considerada ininteligível constituía a causa de tudo que sofria na escola - e em outros espaços. As brincadeiras com as meninas, o gosto por bonecas, o desprezo pelo futebol e pelas brincadeiras consideradas masculinas lhe renderam a vivência de um "inferno na escola", conforme suas próprias palavras.

Ao debruçar seu olhar analítico sobre a vida política contemporânea, Butler (2015:17) afirma que o status de sujeito não é dado a priori a todos os indivíduos, já que "há 'sujeitos' que não são reconhecíveis como sujeitos e há 'vidas' que dificilmente - ou melhor dizendo, nunca - são reconhecidas como vidas". A autora entende que, no mundo social, há normas que operam a distinção dos indivíduos, reconhecendo como sujeitos aqueles que se enquadram nas prescrições e excluindo radicalmente os que estão fora das fronteiras normativas. Dessa maneira, a existência que não sustenta uma continuidade e coerência - construídas socialmente - entre corpo, gênero e desejo constitui-se como "algo que está vivo, mas que é diferente de uma vida" (ibid.:33). 
Assim, Rebeca, não só na escola, mas também em outros espaços sociais, não é tomada como "sujeito", uma vez que sua forma de existir a faz ficar fora dos muros do reconhecimento enquanto "vida". A vida da travesti não é uma vida que importa, passível de luto, antes, ao contrário, é a existência que pode - e deve - ser extirpada, como observamos cotidianamente por todo o Brasil, onde dia a dia multiplicam-se casos de assassinatos contra essas sujeitas, como observa Bento (2014). Butler (2015:20) finaliza levantando questionamentos de como podemos, em vez de enquadrarmos os indivíduos nas normas existentes, mudar os parâmetros que produzem o reconhecimento de sujeitos e vidas que importam ou "em outras palavras, o que poderia ser feito para mudar os próprios termos da condição de ser reconhecido a fim de produzir resultados mais radicalmente democráticos?”.

Contou que certa vez, quando tinha cerca de 12 anos de idade, foi espancada, dentro da escola, no intervalo, por garotos mais velhos, ao ser vista portando um estojo de maquiagem. Sobre o acontecido, disse não ter informado à gestão, pois saberia que se o fizesse, além da surra que havia tomado, iria levar uma bronca, pois maquiagem não deveria ser utilizada por alguém do seu sexo. Introjetou o sentimento de culpa. Acrescentou que, não poucas vezes, recorreu aos professores e funcionários da instituição de ensino pelas violências sofridas e nunca obteve assistência necessária, mas sim uma nova forma de violência, ao ver balizados e justificados os atos cometidos contra ela, sendo culpabilizada pelo que lhe acontecia. O que nos mostra que a homofobia e suas variantes na escola, além de consentida, é estimulada - inclusive pelos próprios educadores - como recurso pedagógico na correção das condutas e na fabricação de uma sexualidade "saudável” (Junqueira, 2009).

Entendendo a escola como uma instituição, portanto, locus de atuação do poder público, através dos agentes que neste espaço personificam seu poder, compartilho com Butler (2015) a ideia de que os casos contemporâneos de violência, em grande parte, estão intrinsecamente relacionados com o Estado. Assim, a escola, enquanto campo estatal que deveria oferecer proteção aos indivíduos- uma representação muito forte no imaginário social - acaba por se tornar algo de que estes devem se proteger, uma vez que se apresenta como lugar da violência, negação e invisibilidade para jovens como os LGBT. Uma das experiências mais dolorosas relatadas por Rebeca disse respeito à postura de uma professora que, ao lhe ver maquiada e de cabelos pintados, afirmou que a estudante se assemelhava a um monstro, a um ser indefinido, que não sabia em que campo do gênero poderia classificá-la, denotando como a homossexualidade e outras existências subalternas são colocadas no âmbito da monstruosidade (Foucault, 2002).

Diante de todos os horrores experimentados no espaço escolar, Rebeca apresentava um baixo rendimento. $\mathrm{O}$ fato de ter saído da casa dos pais e ido morar na residência de uma senhora para quem trabalhava, longe do colégio, agravou sua situação. Afirma que, nessa época, tinha verdadeiro pavor de ir para a escola, entendida como sinônimo de sofrimento, faltando às aulas sempre que possível. Com isso, reprovou o oitavo ano, o que representou o estopim para abandonar os estudos por três anos. Em sua fala, sustentou, portanto, a evidente relação entre a discriminação no ambiente educacional e o baixo rendimento obtido. Afinal, como conseguir aprender em um lugar que violenta sua existência? Em emocionante relato, indagou-se como alguém pode ter boas notas e gosto pela escola se esta não lhe 
recebe, não lhe acolhe e não se mostra interessada no seu bem-estar, sinalizando para a dificuldade das instituições de ensino em dialogar com a diversidade de sujeitos que tomam assento nos seus bancos.

Ainda sobre o processo de aprendizagem, é importante pensarmos na intrínseca relação que este possui com a cultura. Lave (2015) chama atenção para pensarmos a aprendizagem atrelada ao contexto tecido pela cultura, no interior do qual as duas se fazem reciprocamente. A autora acredita ser necessário acionarmos arranjos, movimentos e relações, experimentadas nos diversos ambientes onde os sujeitos se constroem culturalmente, e entender como esses fluxos vividos incidem nos processos de aprendizagem, seja na escola ou em outros espaços. O que quero dizer com isso é que a compreensão de como a aprendizagem ocorre está ligada aos processos culturais mais amplos de uma sociedade, o que nos leva a concluir que os estudantes LGBT podem ter seus itinerários educativos dificultados pela estrutura social de exclusão dos seus corpos e existências, tanto na escola como em outros ambientes.

Após ser reprovada e depois de experimentar tantas experiências humilhantes na escola, Rebeca abandonou durante três anos a sala de aula. Ao ser perguntada acerca do motivo que lhe fez voltar, foi enfática ao responder que o grupo de "bichas" conhecidas da rua onde morava na época configurava-se como grande incentivador para seu retorno. Sua performance tida como feminina não lhe constrangia, nem lhe amedrontava mais como antigamente. É o que observei ao vê-la percorrendo, com muita segurança e intimidade, os espaços da escola. "Uma verdadeira mulher e se vier pra cima, vai ser choque de monstro, querida!" foi o que me respondeu ao ser questionada como se sentia usufruindo da instituição escolar naquele momento.

Não posso afirmar que Rebeca não sofria mais insultos e outras formas de preconceito, mas claro estava para a estudante que tais tipos de agressão não podiam/deviam lhe resultar em sujeição. "Eu existo e sou assim, não vou mudar por nada e por ninguém”, afirmou Rebeca, ao refletir sobre as inúmeras vezes em que tentou enquadrar-se nas normas de gênero. "Se aqui é o inferno, eu sou a principal demônia" configura uma fala dela que explicita seu poder de resistência e seu empoderamento frente a possíveis ameaças e tratamentos discriminatórios. Assim, como nos mostra Rodovalho (2017), a violência que atinge os indivíduos que afrontam e provocam fissuras no ordenamento constituído do gênero não desencadeará uma volta para o armário. Continuarão, portanto, existindo e resistindo, a despeito de todas as múltiplas tentativas de aniquilamento dessas populações.

As "bichas" que Rebeca conhecia na rua onde morava, como já pontuei, foram as grandes incentivadoras da volta da estudante à sala de aula. A rede de sociabilidade que construíram dentro da escola oferece as principais forças que Rebeca afirma ter para permanecer na instituição, corroborando com o posicionamento de Cornejo (2015) ao afirmar que a "amizade queer" 7 é um importante sustentáculo para se agarrar à vida e não sucumbir definitivamente. Por isso, afirmo, mais uma vez, que a escola não pode ser tomada exclusivamente como locus de sofrimento para as juventudes LGBT, posto que as experimentações desse espaço por esses sujeitos são múltiplas. O caso de Rebeca é revelador disso. Ao dizer que quer aproveitar tudo o que a instituição de ensino pode lhe dar, a jovem exemplifica:

\footnotetext{
7 O termo queer possui origem anglófona e, se traduzido literalmente para o português, significa "estranho", "excêntrico". O vocábulo é usado para designar indivíduos que se encontram fora dos padrões cis-heteronormativos.
} 
Eu acho que a escola me roubou muita coisa [...], mas hoje eu quero aproveitar ela, doa a quem doer e dói em muita gente [risos]. Minhas amigas é [sic] tudo pra mim, sabe, ter essas amizades, essas relações que eu não tinha quando era mais novinha, sabe, de ir pra casa uma da outra fazer os trabalhos, estudar, falar dos boys [garotos], né [risos]. Isso é uma coisa que me segura na escola. Tem coisa ruim? Tem, mas tem muita coisa boa que eu não vou abrir mão. Tem muito agora esse negócio de resistir, né? Então, eu aprendi a resistir a essas coisas ruins e aproveito tudo que a escola pode me dar [...], já foi um lugar muito ruim, de muita coisa, memória ruim, mas hoje eu tô aqui e vou ficar e aproveitar. Não dizem que todo mundo tem direito à educação?

Segundo a jovem, as "bichas" com quem possui vínculos de amizade representam força e proteção. Com elas se sente acolhida e parte de um coletivo, com quem pode falar dos seus desejos, anseios e com quem compartilha experiências similares. Interessante perceber que a janela temporal durante a qual Rebeca se manteve longe da escola possibilitou algumas modificações significativas nesse espaço, conforme relata. Relembra, por exemplo, que era a única "bicha” antes; atualmente, já "brotou um monte”. A maior presença desses corpos desviados possibilita mais segurança de sustentar sua identidade.

Seus relatos dão conta da importância da existência de pessoas como ela habitando a escola. Olhar para os lados e enxergar existências semelhantes à sua, com quem pode contar, com quem pode fazer grupos para realizar as atividades, com quem pode partilhar os materiais, os estudos em casa e até mesmo as "colas" nas avaliações, conforme confessou. Além disso, essa rede de sociabilidade das "bichas" e a maior presença delas nesse ambiente, com um pouco mais de abertura e tolerância, são atribuídas por Rebeca a posturas mais inclusivas de alguns professores. A estudante explica que existem alguns educadores que "compram a briga" por elas e que, gradativamente, através de aulas, palestras e outras iniciativas, vêm promovendo mudanças, tanto nos estudantes, como nos demais funcionários da escola.

Andrade (2012), rememorando seu passado, também coloca como central a experiência da amizade com outros(as) desviados(as). Apesar de todas as formas de violências elaboradas contra os indivíduos estigmatizados, por borrarem as normas hegemônicas da sexualidade, seus corpos e experiências nos contextos escolares, por si só, já se configuram como fissuras de uma ordem fundamentada na cisgeneridade e na heterossexualidade, desenhando, através das microrresistências cotidianas, novas formas de existir e experimentar esses espaços.

Se, por um lado, podemos afirmar que a escola produz abjeção e desigualdades através das diferenças, devemos também compreender que, em meio à segregação e exclusão, várias experiências e existências tentam subverter a ordem oficial, de múltiplas formas. Isso inclui desde o enfrentamento direto a uma "resistência muda", como estratégia (Certeau, 1994) de permanência na instituição de ensino, pois esta é a garantia de aberturas e transformações a curto e longo prazo. Assim, emaranhados em teias de relações de poder assimétricas, os jovens LGBT buscam manter sua "agência" (Ortner, 2007b), criando resistências e fissuras nos arranjos culturais onde estão inseridos.

8 Nesse contexto, a palavra é usada para definir o ato de compartilhar as respostas de uma avaliação individual, geralmente escritas em pequenos pedaços de papel, com um colega de classe. 


\section{Reinvenções e resistências: aproveitando o espaço da escola}

Para Ortner (2007b), não podemos pensar o poder de forma monolítica, pois este apresenta uma dupla face: de dominação - exercido de cima para baixo - e de resistência - exercido de baixo para cima. Se a dinâmica e a condução da escola buscam invisibilizar, negar e até mesmo expulsar a existência LGBT do seu meio, também observamos o movimento contrário, a resistência que se exerce quando esses estudantes se mantêm nesses espaços e, sobretudo, enfrentam e subvertem a ordem estabelecida.

Dessa forma, por um lado, é verdade que podemos tomar a escola como lugar, por excelência, de sofrimento para as juventudes LGBT, de outro, sua presença nesse ambiente também promove brechas. É no consumo cotidiano da instituição que ressignificam vivências, transformam sua realidade e penso que, ainda mais, daqueles e daquelas que virão depois. Criam fissuras por dentro que, embora pouco percebidas, estão lá operando para revolver as normas hegemônicas do gênero. A própria Rebeca informou que "quanto mais o tempo passa, eu sinto que vão encarando melhor", referindo-se à sua percepção na atualidade acerca de uma experiência escolar menos dura, se comparada a anos anteriores.

Os jovens estudantes LGBT se equilibram num jogo entre aceitar e resistir. Possuem uma postura marcada, muitas vezes, pela racionalidade e "pesam" na balança em que situações valerá ou não a pena transgredir as normas, como observamos em alguns depoimentos. Sabem que precisam estar na escola e que, portanto, não podem fazer tudo o que desejam, entretanto, isso não significa cega obediência disciplinar. Rebeca, por exemplo, gostaria de usar o banheiro feminino, o que é proibido severamente pela direção. Afirmou ser obrigada a respeitar a decisão, pois sabe que, se burlar essa regra, seria expulsa da escola - embora o documento final da Conferência Nacional de Lésbicas, Gays, Bissexuais e Travestis (Brasil, 2008) assevere que a estrutura dos espaços escolares deve ser usufruída em conformidade com a identidade de gênero dos(as) estudantes.

Contudo, outras normas não são obedecidas, como, por exemplo, o uso do tênis. Segundo Rebeca, só às mulheres é permitido a utilização de outro calçado que não o tênis e a direção já lhe havia comunicado que não usasse sandálias femininas - o que deixa claro que a instituição não reconhece sua identidade de gênero. Para entrar na escola, sob o olhar vigilante dos funcionários, ela usa o tênis, mas, ao chegar à sala de aula, pega na bolsa uma sandália "bem bonita e cheia de frufru”, às vezes, com salto alto.

A proibição ao namoro costuma ser outra norma via de regra burlada por todos os jovens da escola, incluindo os LGBT. O discurso oficial das três instituições pesquisadas é que práticas e demonstrações afetivas são rigorosamente proibidas no interior desses espaços. Num dos ambientes de investigação, era comum que os estudantes LGBT afirmassem que, na verdade, se tinha uma norma exclusiva para a proibição dos afetos não heterossexuais, já que viam constantemente meninos e meninas trocando carícias no intervalo, geralmente ao redor de uma das quadras esportivas e a direção fazia "vista grossa" para essa prática, revelando o quanto o discurso oficial da homogeneidade de tratamento ("são todos tratados de igual forma") não se concretiza no dia a dia (Dayrell, 2007). Enquanto os normatizados possuíam seus momentos de flerte e namoro tolerados pelos funcionários, os jovens 
assumidamente LGBT, conforme relatam, tinham seus passos constantemente vigiados em horários livres, como o intervalo e a educação física, quando faziam uso dos banheiros.

Patrícia, estudante de 17 anos, lésbica, afirmou que a direção colocava os professores para acompanhar seus rastros durante o intervalo, pois todos sabiam de seu namoro com outra colega da mesma escola. "E assim era com muita gente também", completou a jovem. Patrícia diz que já foi chamada pela gestão várias vezes para ser informada e advertida que a instituição não permitiria, de maneira alguma, práticas afetivas no seu espaço. Diante de funcionários e docentes, promete que evitará a conduta referida e afirma saber da importância do cumprimento de todas as medidas da escola. Todavia, a estudante, embora com receio, busca driblar a regra e contou se encontrar, sempre que possível, com sua namorada, até mesmo porque, como sua família não permitia o relacionamento, o horário escolar constituía um dos poucos momentos em que podiam estar juntas. Ela afirma que "dá pra fazer isso e continuar sendo vista como boa aluna" - a "boa aluna" faz referência à conformidade com as normas hegemônicas do gênero e da sexualidade:

Tem a escola que proíbe e tem todo mundo fazendo de tudo pra não acontecer, mas dá pra escapar das regras, sempre dá. Então, quando a gente quer, a gente consegue, dribla todo mundo [risos]. Eu tenho medo porque não quero ser expulsa, Deus me livre e quero continuar sendo bem tratada pelos professores e tal, porque tipo ser "sapatão" é ser a má aluna, a revoltada, né e tal. Então a gente tenta sempre se ver discretamente pra ninguém brigar, porque se virem já brigam, fazem o circo, né.

Igor e Fernando, estudantes gays de outra escola, ambos com 17 anos, vivem situação similar à de Patrícia. O namoro assumido na escola proporciona uma maior vigilância na rotina dos jovens. A disciplina não opera sem resistência também nesse caso. Fernando, por exemplo, afirmou que a estratégia que utilizam para garantir rápidos encontros é ir ao banheiro durante o horário das aulas. Segundo relata, trata-se de uma alternativa só para poderem conversar "mais de boa". Como nesse período o banheiro fica pouco movimentado e dificilmente terá um funcionário, os jovens combinavam o horário para o encontro por mensagem pelo aplicativo WhatsApp. Solicitavam, assim, ao professor(a) permissão para deixar a sala de aula no mesmo momento, já que estudavam em turmas diferentes e, dessa forma, podiam desfrutar melhor da companhia um do outro. De acordo com Fernando, nunca houve problemas, sequer algum tipo de desconfiança, por parte dos professores. Como Patrícia, Fernando afirma que ser um "aluno gay" é sempre lido pela escola como "mau aluno", um "aluno trabalhoso".

Os estudantes LGBT da escola fazem, logo, uma bricolagem com a norma sempre que podem, tentando medir custos e benefícios - burlar a regra, mas evitar medidas mais duras da escola, como suspensão e expulsão, por exemplo. Dessa forma, observamos, em consonância com o pensamento de Ortner (2007a; 2007b), como as relações entre indivíduos e estruturas sociais são dinâmicas. Conforme a perspectiva da autora, é necessário compreender como as pessoas, mesmo em relações de poder assimétricas, encontram formas de resistência à ordem estabelecida. Assim, busco entender as experiências escolares desses jovens sob a ótica da "teoria da prática”, abraçada por Ortner, focalizando desejos e intencionalidades de sujeitos subalternizados na vida social e que, mesmo nessa condição, usam as cartas que têm dentro do jogo social. 
Portanto, contra a disciplina que opera tentando negar suas existências, seus corpos e subjetividades, há a contraofensiva desses estudantes dentro do exercício da autoridade. A agência, para Ortner (2007b), se concretiza em um contexto de poder. A resistência à ordem empodera os sujeitos subversivos. Enquanto a escola busca expulsá-los do seu interior, alguns alunos tecem relações de não assujeitamento, mostrando não serem despossuídos de agência, entendida aqui como relacionada "com o fato de agir no contexto de relações de desigualdade, de assimetria e de forças sociais" (ibid.:58).

Como dito, a agência, para Ortner, deve ser entendida fortemente vinculada à distribuição dos recursos de poder, sobretudo quando analisamos situações relacionadas às relações de gênero, no âmbito das quais, historicamente, mulheres, gays, lésbicas, bissexuais e travestis têm sofrido uma tentativa de alijamento total de sua capacidade de agir. Observamos, contudo, que as situações aqui exibidas mostram que os estudantes LGBT agem nas minúcias do cotidiano, de diferentes formas, para fabricar uma ordem mais democrática e favorável a si mesmos.

Agindo no mundo social - pois Ortner (2007b) entende que todos os indivíduos possuem algum recurso, ainda que restrito, para a agência de poder -, nas suas experiências concretas e nas práticas sociais engendradas, os indivíduos transformam e reproduzem, simultaneamente, a cultura onde operam. Assim, os estudantes LGBT não estão simplesmente presos às estruturas de poder, mas agem com criatividade - embora com limites e poucas possibilidades. Mostramos, etnograficamente, como esses sujeitos constroem fissuras no sistema e rompem com o ordenamento oficial. Se não é permitido o uso de salto alto pelas travestis, os namoros entre jovens gays e lésbicas, o jogo de futebol para as meninas, o que a realidade fabricada cotidianamente aponta é a inventividade desses alunos ao consumir os espaços escolares, onde, mesmo com limitadas possibilidades, ressignificam seus contextos.

É com a ressignificação que esses indivíduos tornam a escola um "lugar habitável”, conseguindo frequentá-la todos os dias. É mostrando como transformam a rotina estudantil em momentos mais palatáveis que os discursos dos jovens LGBT apontam para aspectos positivos de vivenciar esse universo. As práticas afetivas entre Patrícia e sua namorada, por exemplo, são sentidas pela jovem como algo de bom por estar na escola. Ter a possibilidade de jogar vôlei no horário do intervalo, para Roberto, jovem gay de 16 anos, aluno do primeiro ano do Ensino Médio, configura o que lhe motiva a frequentar a instituição de ensino, pois na sua casa seu pai lhe obriga ao futebol com os meninos da rua, uma tortura psicológica diária, segundo relata. A escola, como vemos, pode ser também refúgio para muitos estudantes LGBT.

Mesmo entre aqueles que não conseguem ressignificá-la e a tomam como ambiente tóxico, que não tolera sua existência enquanto LGBT, há uma perspectiva positiva do processo de educação formal. Muitos discursos sinalizam a valorização da instituição escolar enquanto alicerce e arcabouço de delineação do futuro. Roberto acenou para essa posição, ao afirmar que "aguenta" os sofrimentos das vivências estudantis por um objetivo maior. Vindo de uma família pobre, é consciente de que o futuro será resultado dos itinerários formativos que a educação pode lhe oferecer.

Dessa forma, é pela projeção do porvir que Roberto suporta, todos os dias, os garotos da escola o chamarem de "viadinho" e outros apelidos que soam jocosamente, para o riso daqueles ao redor. Da mesma maneira, Andrade (2012, 2015), a primeira travesti brasileira doutora e professora universitária 
com cargo efetivo, recorda as dificuldades que enfrentou no seu percurso discente. Olhando para trás, a autora relembra que "mesmo em um ambiente escolar de negação da minha forma de brincar e de ser, eu tinha um projeto que superava a dor física e psicológica que vivenciava diariamente: era estudar e aprender, objetivando conseguir um bom emprego para ajudar minha família" (Andrade, 2015:57).

Resignar-se aos obstáculos do cotidiano escolar impostos aos estudantes LGBT é também estratégia adotada por parte destes, inclusive, abrange forçar comportamentos que não denunciem sua homossexualidade, para obter os privilégios dos normatizados. Essa postura é observada com Caio, por exemplo, estudante de 17 anos, do segundo ano do Ensino Médio de uma das instituições pesquisadas, que afirmou não querer "dar pinta”. Entendo que se submeter às normas configura, por vezes, também uma espécie de resistência, de não definhar em meio a um espaço hostil à sua existência. Esconder-se para existir. Embora queira ensaiar uma performance cotidiana que denomina de "afeminada" (que seria sua verdadeira identidade, conforme relata), Caio contou que isso lhe traria prejuízos, uma vez que os professores e a direção iriam "implicar”, além de gerar uma difícil convivência com os colegas.

Assim, a melhor opção é ser um "gay comportado", de acordo com suas próprias palavras, já que assim o tempo escolar é vivido sem grandes perturbações, podendo tirar maiores vantagens - numa perspectiva utilitarista - dessa experiência. Tal posicionamento encontra ratificação também no campo etnográfico de Bento (2006:209), que constata, entre suas interlocutoras, transexuais em processo de transição, maior nível de escolaridade justamente entre aquelas que dissimularam seus desejos, num "esforço considerável para não dar pistas”.

Caio e Roberto, bem como muitos outros estudantes LGBT, afirmam saber que precisam da escola para poder vislumbrar um futuro melhor para si e para a família - e até mesmo poder viver sua homossexualidade da forma desejada, pois um bom emprego e dinheiro são condições necessárias para isso, conforme explicitam. Por conseguinte, observamos a outra face da noção de agência proposta por Ortner (2007:58): "agência tem a ver com intencionalidade e com o fato de perseguir projetos (culturalmente definidos)". Ademais, é comum nas falas dos alunos a menção aos projetos de vida, que são plurais, mas todos eles passam pela necessidade de garantir um bom percurso formativo na Educação Básica, pois conforme garantiu Caio, por exemplo, é a escola e o que dela se tirar proveito que definirão seu futuro, o que sinaliza a centralidade que essa instituição possui para as juventudes.

As experiências de estudantes LGBT, como pudemos verificar, são marcadas pela heterogeneidade. Resignando-se à norma, reinventando o cotidiano através de fissuras e resistências, no jogo entre assujeitamento e dissidência, constroem seus caminhos em meio a uma multiplicidade de relações e estruturas, que se metamorfoseiam com as ações cotidianas, diante da ação de atores subjetivamente complexos.

\section{Considerações finais}

O artigo ora apresentado não possui a intenção de exaurir a totalidade da multifacetada realidade desenhada nos espaços escolares por discentes LGBT, mas buscou contribuir, através dos fragmentos discursivos apresentados, somados à discussão teórica acoplada, com o debate acerca desses 
ambientes, seus usos e significados conferidos por estudantes que fogem à norma dominante do gênero e da sexualidade.

É notório como a escola e o tempo escolar são vividos sob o viés do sofrimento pelos sujeitos investigados, sobretudo para aqueles que mais se distanciam dos modelos hegemônicos de gênero ainda que, conforme quis destacar, não possamos tomar as instituições de ensino unicamente por esse viés, pois os próprios jovens LGBT se reinventam e se apropriam desses espaços de múltiplas formas. Suas experiências e itinerários são heterogêneos, adotando diferentes táticas de permanência. De um enfrentamento mais direto a um posicionamento mais velado ou mesmo à resignação em aceitar não viver como se quer e expressar o que se é, os estudantes LGBT estão na escola, criando através da sua capacidade de "agência" (Ortner, 2007) formas de resistir às opressões observadas no dia a dia e denunciadas nas suas falas.

Quero chamar atenção, nesse sentido, para a necessidade de não homogeneizar as vivências escolares desses indivíduos. Não podemos subsumi-las à mera dominação e ao sofrimento, sob pena de perdermos os movimentos que orquestram a realidade, uma vez que os sujeitos sociais, agindo nos seus cotidianos, resistem inventivamente à ordem estabelecida. Ao mesmo tempo, não podemos relativizar a homofobia e suas variáveis sofridas nesses espaços, sintonizadas com os ditames da cis-heteronormatividade.

Precisamos entender a educação como campo político essencial para a luta pela ampliação dos direitos dos sujeitos, que contemplem a vivência da diversidade e o reconhecimento da igualdade. É na arena da educação que podemos disputar as narrativas capazes de possibilitar a construção de um espaço social mais aberto e democrático. E, para isso, mostra-se possível nos utilizarmos da produção do conhecimento antropológico no campo do gênero e da sexualidade, de modo a pensar políticas públicas que consigam efetivar esse alargamento da cidadania para sujeitos LGBT. Sobretudo numa época de recrudescimento conservador contra os direitos desses sujeitos, que passa por diversos âmbitos, incluindo a seara educacional, palco de uma explosão de disputas políticas e institucionais sobre as questões de gênero e sexualidade nas escolas (Junqueira, 2018; Carrara, França e Simões, 2018).

No Brasil, hoje, é preciso lutar contra a atual conjuntura de um Estado de imposição moral, marcado por movimentos neoconservadores - especialmente no âmbito legislativo - com estreita relação com princípios religiosos. Machado (2017) afirma que o crescimento do poder político no Congresso Nacional de uma bancada religiosa, alicerçada na heterossexualidade como princípio obrigatório, tem produzido narrativas e fortes oposições aos direitos LGBT e atingido também as principais pautas feministas.

Os obstáculos impostos ao processo de descriminalização do aborto e a tentativa de retirada das discussões sobre gênero e sexualidade na escola vêm se revelando fortes estratégias do parlamento brasileiro para impor os fundamentos religiosos acima dos constitucionais. Devemos, portanto, defrontar esses empreendedores morais que, ao trabalhar pelo fechamento do debate nas instituições de ensino, desejam aprofundar ainda mais as dificuldades de estudantes LGBT e afastá-los da condição de huma- 
nidade e cidadania (vide o projeto "Escola sem Partido"') e, ao mesmo tempo, fazer o Estado operar como entidade heterossexual, que elimina os sujeitos de sexualidade e gênero dissidentes da sua agenda (Miskolci e Campana, 2017).

Faz-se necessário ampliar nossos horizontes analíticos, teóricos e empíricos no que concerne ao tratamento da escola em relação à diversidade - não só no que diz respeito a gênero e sexualidade, como também a aspectos étnico-raciais, religiosos, de classe, etc. Precisamos refletir sobre tais questões, sob pena de, não o fazendo, naturalizarmos os sofrimentos que a homolesbotransfobia escolar produz e sermos cúmplices, pelo silêncio, de um maior distanciamento entre as diversas juventudes e a educação formal.

José Ricardo Marques Braga é mestre e doutorando em Antropologia Social pela Universidade Federal do Rio Grande do Norte (PPGAS/UFRN). Professor da Secretaria da Educação Básica do Ceará.

\section{REFERÊNCIAS}

Andrade, L. N. de. (2012). Travestis na escola: assujeitamento e resistência à ordem normativa (Tese de Doutorado). Universidade Federal do Ceará, Fortaleza.

Andrade, L. N. de. (2015). Travesti: ser doutora e educadora é possível. In: B. Bento \& V. Félix (orgs). Desfazendo o gênero: subjetividade, cidadania, transfeminismo (pp. 53-83). Natal: EDUFRN.

Badinter, E. (2011). O conflito, a mulher e a mãe. Rio de Janeiro: Record.

Bento, B. (2006). A reinvenção do corpo: sexualidade e gênero na experiência transexual. Rio de Janeiro: Garamond.

Bento, B. (2011). “Na escola se aprende que a diferença faz a diferença." Revistas Estudos Feministas, 19(2), 549-559. https://doi.org/10.1590/S0104-026X2011000200016

Bento, B. (2014). Brasil: pais do transfeminicídio. http://www.clam.org.br/uploads/arquivo/Transfeminicidio_Berenice_Bento.pdf

Bourdieu, P. (2002). A dominação masculina. 2a ed. Rio de Janeiro: Bertrand Brasil.

Brasil (2008). Conferência Nacional de lésbicas, gays, bissexuais e travestis. Documento final. Brasília.

9 Movimento político que proliferou no Brasil a partir de 2004, com o objetivo de restringir discussões em sala de aula de natureza política, sobretudo os temas relacionados com direitos humanos, gênero e sexualidade. O Programa Escola sem Partido foi declarado inconstitucional pelo Superior Tribunal Federal (STF) em 2020, mas antes disso, sobretudo em 2014, teve forte repercussão nas pautas educacionais, notadamente no Plano Nacional de Educação daquele ano. 
Butler, J. (2003). Problemas de gênero: feminismo e subversão da identidade. Tradução de R. Aguiar. Rio de Janeiro: Editora Civilização Brasileira.

Butler, J. (2015). Quadros de Guerra: quando a vida épassivel de luto? 1 $1^{\mathrm{a}}$ ed. Rio de Janeiro: Civilização Brasileira.

Carrara, S. \& Simões, J. (2014). O campo de estudos socioantropológicos sobre diversidade sexual e gênero no Brasil: ensaio sobre sujeitos, temas e abordagens. Cadernos Pagu, 42, 75-98. http://dx.doi. org/10.1590/0104-8333201400420075

Carrara, S., França, I. L. \& Simões, J. A. (2018). Conhecimento e práticas científicas na esfera pública: antropologia, gênero e sexualidade. Revista de Antropologia, 61(1), 71-82. https://doi. org/10.11606/2179-0892.ra.2018.145514

Certeau, M. de. (1994). A invenção do cotidiano. v. 1, Artes de fazer. Petrópolis: Vozes.

Connell, R. (1995). Políticas da masculinidade. Educação e realidade, 20(2), 185-205. https://seer. ufrgs.br/educacaoerealidade/article/view/71725/40671

Cornejo, G. (2015). Por uma pedagogia queer da amizade. Áskesis, 4(1), 130-142. https://doi. org/10.46269/4115.47

Costa Novo, A. L. (2015). O armário na escola: regime de visibilidades de professoras lésbicas e gays. (Dissertação de Mestrado). Universidade Federal de Santa Catarina, Florianópolis.

Dayrell, J. T. (2007). A escola faz juventudes? Reflexões em torno da socialização juvenil. Educação e Sociedade, 28(100), 1105-1128. https://doi.org/10.1590/S0101-73302007000300022

Eribon, D. (2008). Reflexões sobre a questão gay. Rio de Janeiro: Companhia de Freud.

Foucault, M. (1988). A história da sexualidade. v. 1, A vontade de saber. Rio de Janeiro: Edições Graal.

Foucault, M. (2002). Os anormais. São Paulo: Martins Fontes.

Grossi, M. (2003). Gênero e parentesco: famílias gays e lésbicas no Brasil. Cadernos Pagu, 21, 261 280. https://doi.org/10.1590/S0104-83332003000200011

Junqueira, R. D. (2009). Diversidade sexual na educação: problematizações sobre a homofobia na escola. Brasília: UNESCO.

Junqueira, R. D. (2018). A invenção da "ideologia de gênero": a emergência de um cenário político-discursivo e a elaboração de uma retórica reacionária antigênero. Revista Psicologia Política, 18(43), 449-502. http://pepsic.bvsalud.org/pdf/rpp/v18n43/v18n43a04.pdf 
Lave, J. (2015). Aprendizagem como/na prática. Horizontes Antropológicos, 21(44), 37-47. http:// dx.doi.org/10.1590/S0104-71832015000200003

Louro, G. L. (2000). O corpo educado - Pedagogia da sexualidade. $2^{\text {a }}$ ed. Belo Horizonte: Autêntica. Louro, G. L. (2014). Gênero, sexualidade e educação: uma perspectiva pós-estruturalista. 16 a ed. Petrópolis: Vozes.

Machado, L. Z. (2014). Interfaces e deslocamentos: feminismos, direitos, sexualidades e antropologia. Cadernos Pagu, 42, 13-46. http://dx.doi.org/10.1590/0104-8333201400420013

Machado, L. Z. (2017). O aborto como direito e o aborto como crime: o retrocesso neoconservador. Cadernos Pagu, 50, e17504. http://dx.doi.org/10.1590/18094449201700500004

Miskolci, R. \& Campana, M. (2017). "Ideologia de gênero": notas para a genealogia de um pânico moral contemporâneo. Sociedade \& Estado, 32(3), 725-747. http://dx.doi.org/10.1590/s010269922017.3203008

Oliveira, M. R. G. (2017). O diabo em forma de gente: (r)existências de gays afeminados, viados e bichas pretas na educação. (Tese de Doutorado). Universidade Federal do Paraná, Curitiba

Ortner, S. (2007a). Uma atualização da teoria da prática. In: M. Grossi, C. Eckert \& P. Fry (orgs). Conferências e diálogos: saberes e práticas antropológicas (pp. 19-44). Brasília: ABA; Blumenau, Nova Letra.

Ortner, S. (2007b). Poder e projetos: reflexões sobre a agência. In: M. Grossi, C. Eckert \& P. Fry (orgs). Conferências e diálogos: saberes e práticas antropológicas (pp. 45-80). Brasília, Blumenau: ABA, Nova Letra.

Rich, A. (2010). Heterossexualidade compulsória e existência lésbica. Bagoas, 4(5),17-44. https:// periodicos.ufrn.br/bagoas/article/view/2309/

Rodovalho, A. M. (2017). O cis pelo trans. Revista Estudos Feministas, 25, 365-373. https://doi. org/10.1590/1806-9584.2017v25n1p365

Rubin, G. (1986). El tráfico de mujeres: notas sobre la "economía política” del sexo. Nueva Antropologia, 8(30), 95-145. https://revistas-colaboracion.juridicas.unam.mx/index.php/nueva-antropologia/ article/view/15478/13814

Seffner, F. (2011). Um bocado de sexo, pouco giz, quase nada de apagador e muitas provas: cenas escolares envolvendo questões de gênero e sexualidade. Revista Estudos Feministas, 19(2), 561-572. https://doi.org/10.1590/S0104-026X2011000200017 
Vianna, A. \& Lowenkron, L. (2017). O duplo fazer do gênero e do Estado: interconexões, materialidades e linguagens. Cadernos Pagu, 51, e175101. http://dx.doi.org/10.1590/18094449201 700510001

Wacquant, L. (2000). Putas, escravos e garanhões: linguagem de exploração e de acomodação entre boxeadores profissionais. Mana, 6(2), 127-146. https://doi.org/10.1590/S010493132000000200005 


\title{
“SE AQUI É O INFERNO, EU SOU A PRINCIPAL DEMÔNIA!": ETNOGRAFANDO AGÊNCIAS JUVENIS LGBT EM CONTEXTOS ESCOLARES DE FORTALEZA/CE
}

Resumo: O artigo busca trazer à luz experiências cotidianas das juventudes LGBT em escolas públicas da capital cearense, buscando compreender como esses sujeitos se constroem nesses contextos, como se relacionam com esses espaços e com todos os outros atores sociais que compõem o cenário educacional. Alicerçado pela etnografia nessa investigação, elejo as técnicas de observação participante e conversas informais, com diversos sujeitos envolvidos nos processos educativos, como forma de entender as lógicas de sentido tecidas nos seus cotidianos. Os dados obtidos apontam uma realidade complexa e multifacetada, em que se observa a produção de maneiras múltiplas de experimentar a escola, que variam de uma dominação pela norma até formas de enfrentamento mais explícitas e que, de uma forma ou de outra, impactam na (re)produção e transformação do regramento em torno do gênero e da sexualidade, construindo fissuras na cis-hetero-norma, por onde sujeitos tidos por desviantes caminham, prosseguem e se (re)fazem, mostrando seu poder de agência.

Palavras-chave: Juventudes LGBT; Experiências escolares; Gênero e sexualidade; Corpos e subjetividades; Agência.

\section{“IF HERE IS THE HELL, I AM THE MAIN DEVIL!”: AN ETHNOGRAPHY OF THE LGBT YOUTH AGENCIES IN SCHOOL ENVIRONMENTS FROM FORTALEZA (CE)}

\begin{abstract}
This article contemplates experiences of LGBT youth in public schools in Fortaleza city, capital of Ceará State, Brazil, seeking to understand how these individuals construct themselves in these contexts, how they relate to these spaces, and with all the other social actors that make up the educational scenario. Based on ethnography in this research, I choose the techniques of participant observation and informal conversations, with different subjects involved in the educational processes, as a way to understand the logic of meaning woven into their daily lives. The data obtained points to a complex and multifaceted reality, in which the production of multiple ways of experiencing school is observed, ranging from domination by the norm to more explicit forms of confrontation and that, one way or another, impact on (re)production and transformation of the rules around gender and sexuality, building cracks in the hetero-cis-norm through which subjects considered as deviant walk, continue and (re)make themselves, showing their power of agency.
\end{abstract}

Keywords: LGBT youth; Schooling experiences; Gender and sexuality; Bodies and subjectivities; Agency.

RECEBIDO: $18 / 05 / 2020$

APROVADO: 11/01/2021 